\title{
نزعة العولمة وأوجه المثاقفة في العرض المسرحي العراقي - مسرحية (الاسكاني) أنموذجا-
}

أ.م .د / زهـير كاظمه

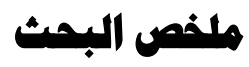

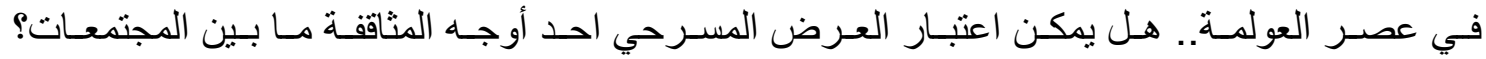

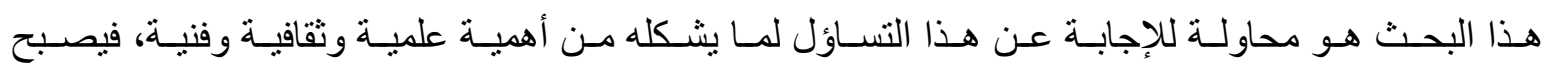

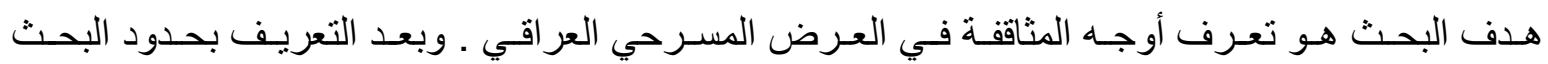
الذي اختار مسرحية (الاسكافي) انموذجـاً والتسي برر الباحث اختيـاره لها لأسباب عدة مـن أهمها أنها

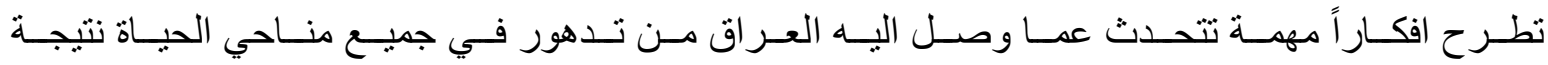

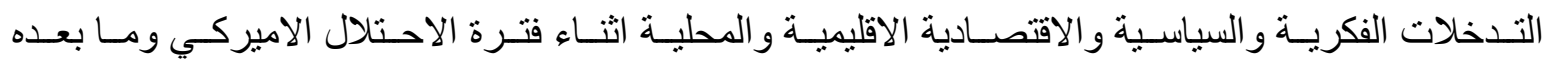

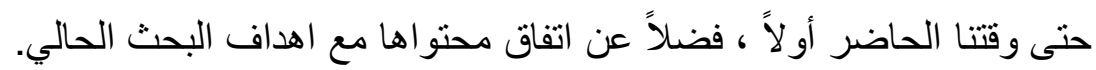

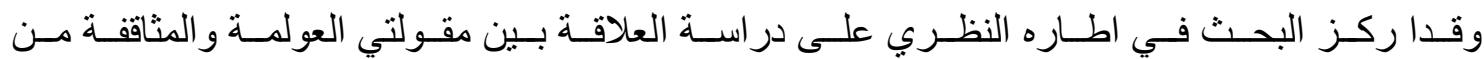

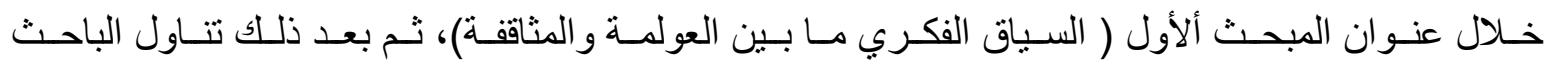

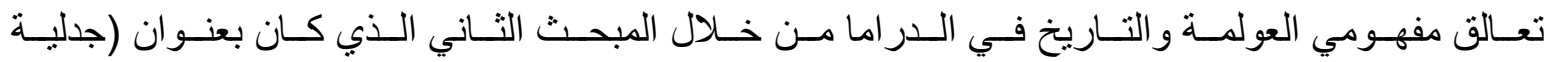

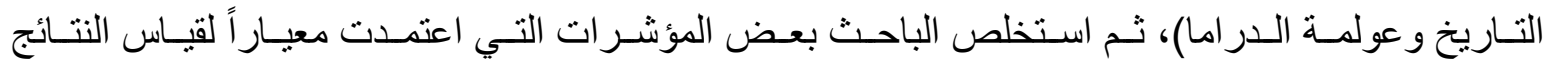

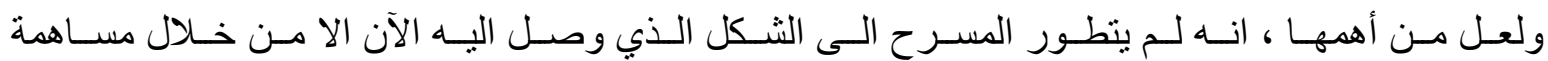
جميع الأمم وتداخل تجاربهم مع بعضها دون استثناء..

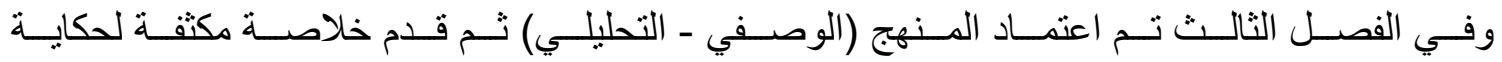

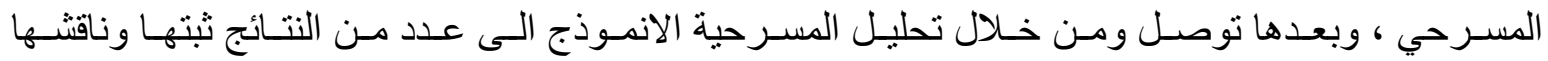

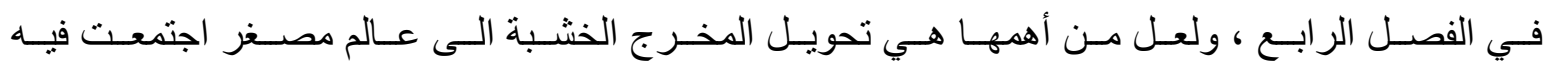

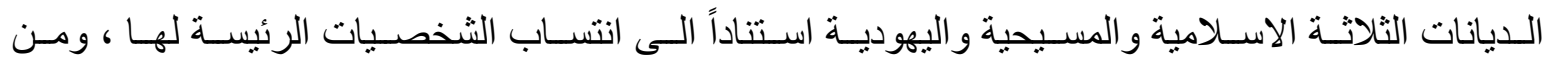

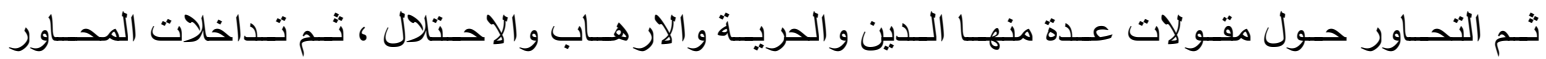

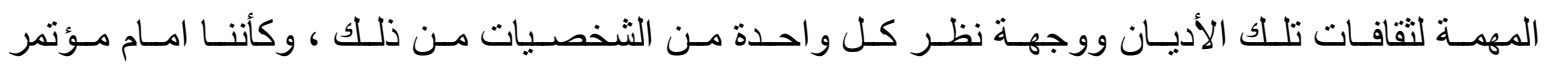

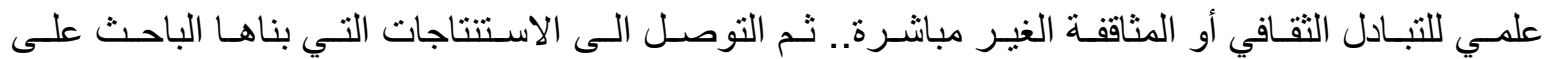
ما حصل من نتائج وانتهى البحث بقائمة الدصادر.

\section{مشكالة البمث والهاجة اليه}

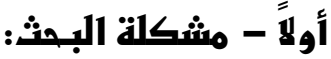

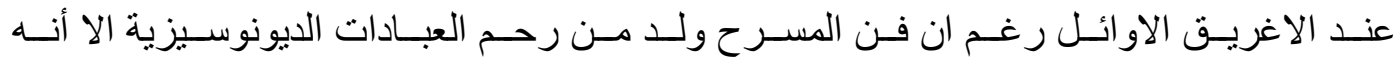

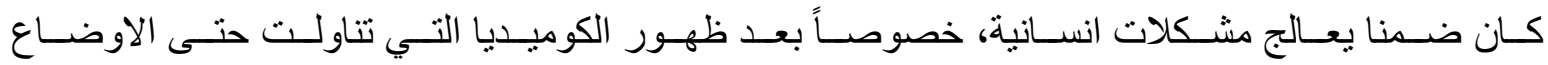

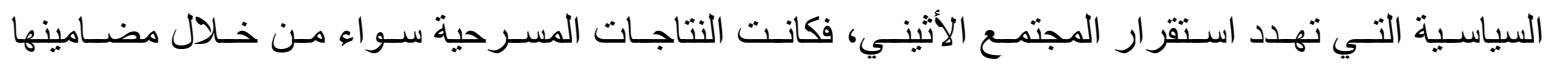

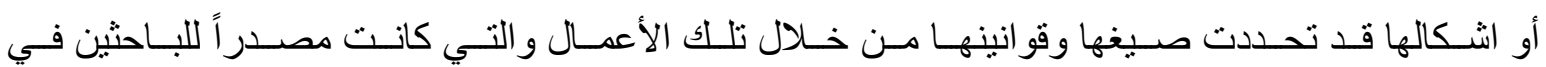




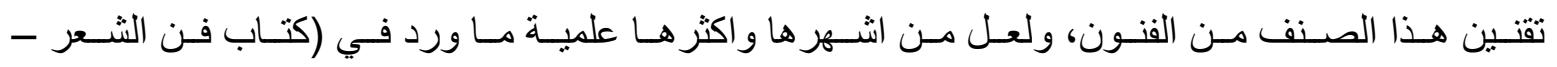

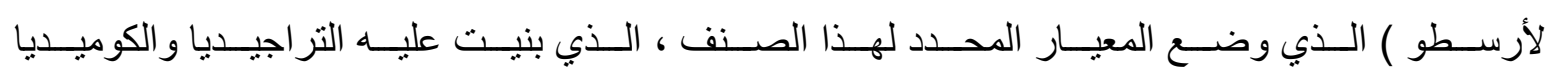

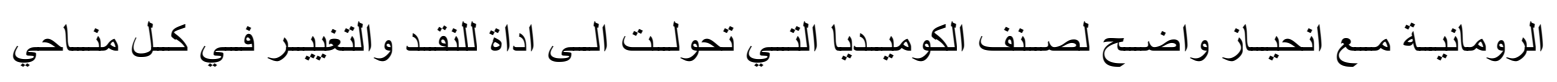

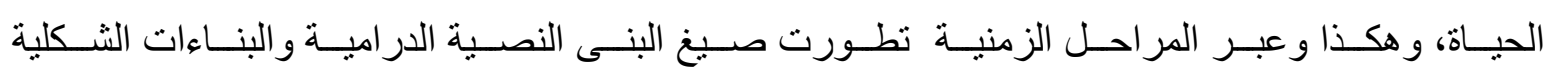

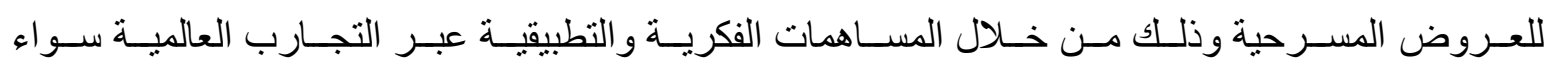

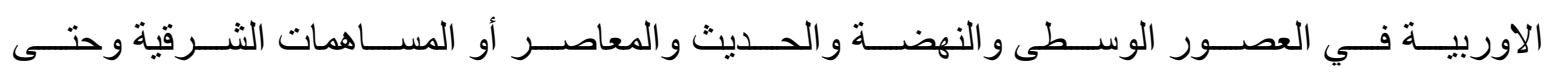

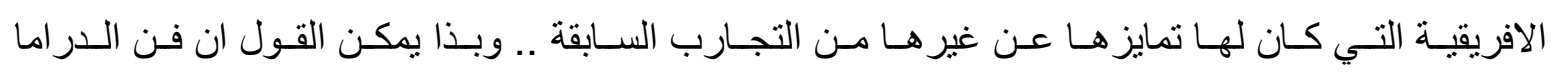

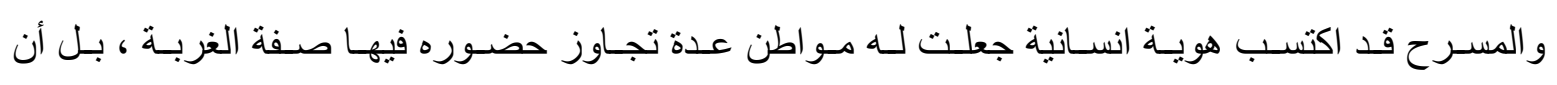

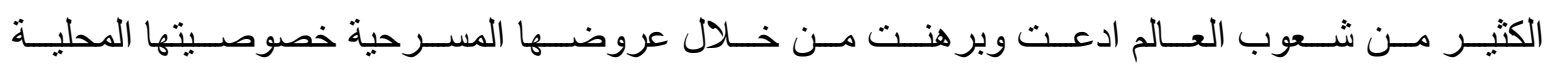

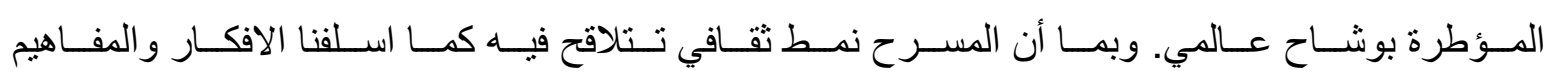

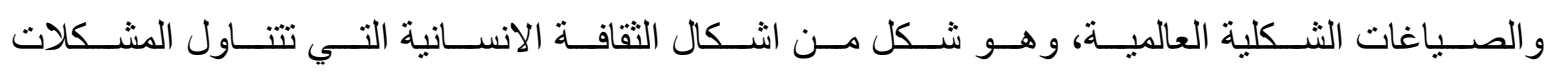

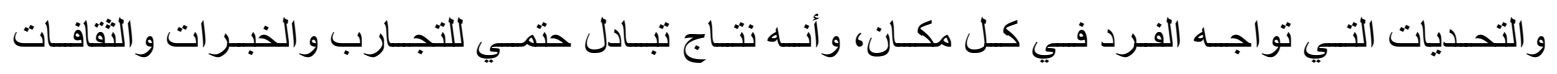

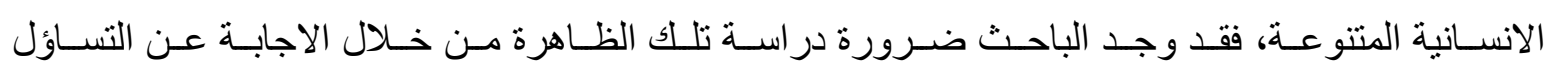
الآتي: (هل يمكن اعتبار الظاهرة المسرحية أحد أوجه المثاقفة في عصر العولمة)

$$
\text { ثانياً - - ندف البهث : - بهدف البحث الى : }
$$

تعرف اوجه المثاقفة في العرض المسرحي العراقي ، باعتبارها احدى صور العولة.

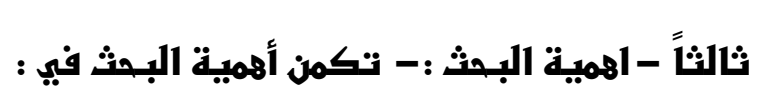

أـ كونه احدى الدراسات العلمية التي تعني بمعرفة مدى التداخل المفاهيمي بين العولمة والمسرح ب - يفيد الباحثين و الدارسين والعاملين في مجال الفنون المسرحية.

$$
\begin{aligned}
& \text { رابعاًا - هدود البـث : - ـ }
\end{aligned}
$$

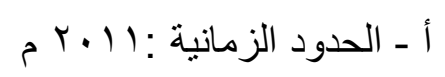

ب - الحدود المكانية :كلية الفنون الجميلة / بغداد / مسرح حقي الثبلي

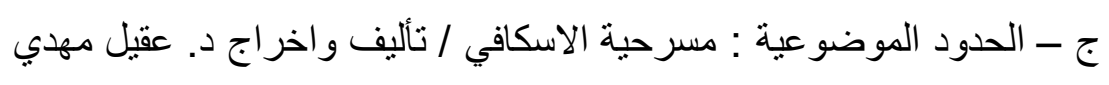
خامساً - تعريف 1 المصطلحات :-

1 ـ العولمـة: هـي: "ظــاهرة الانتمـاء العـالمي بمعنــاه العـام ، وهـي تعبيـر مختصـر عـن مفــاهيم

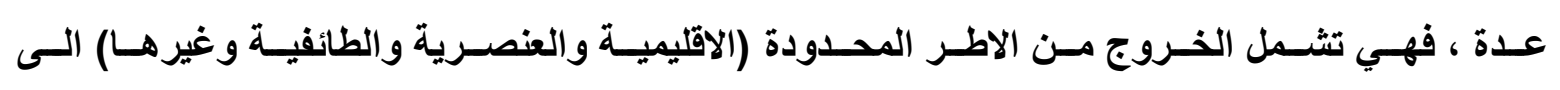

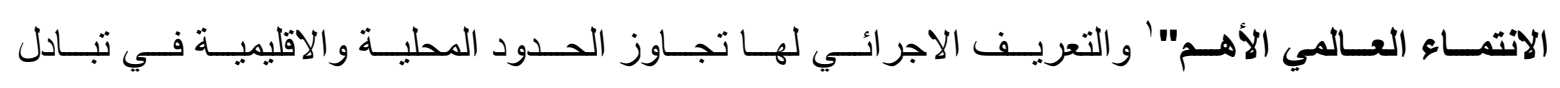
النتاجات الانسانية في كافة الميادين. r- المثاقفـة : هـي "مجموعـة الظـواهر الناتجـة عـن احتكـاك مسـتمر ومباشـر بـين مجموعـات أفراد

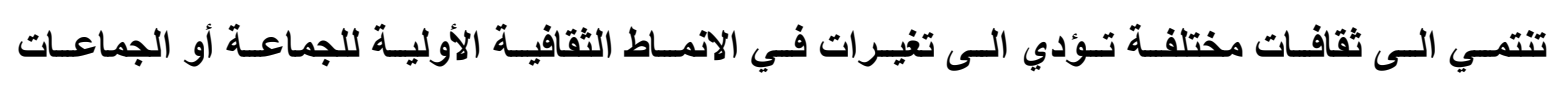

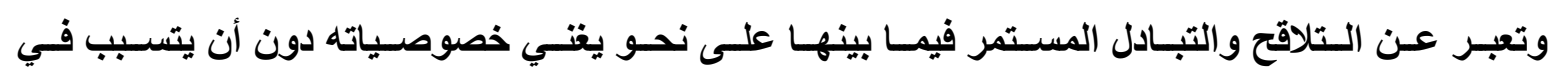




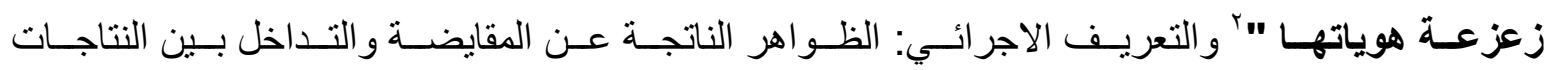
الثقافية للمجتمعات المتعددة.

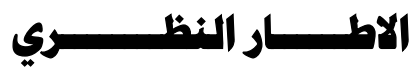

\section{المبـــث الأول: السياق الفكري ما بين العولمة والمثاقفة :}

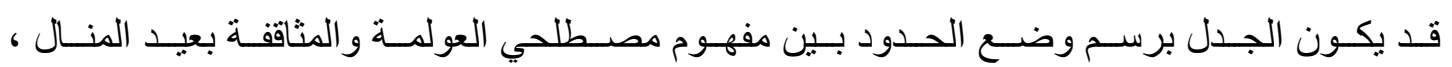

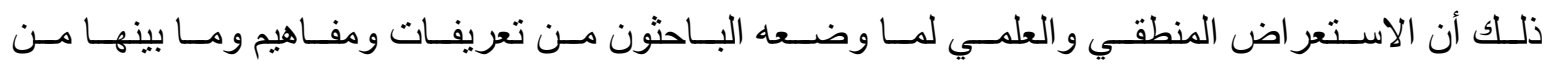

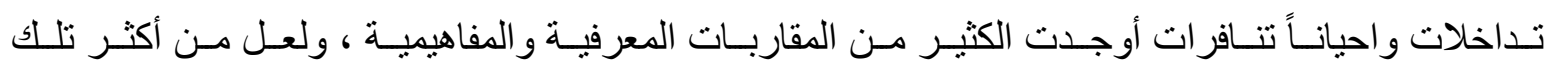

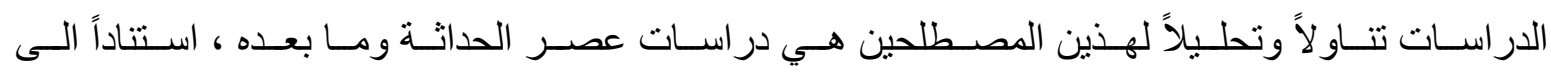

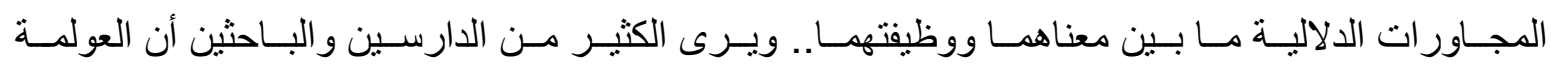

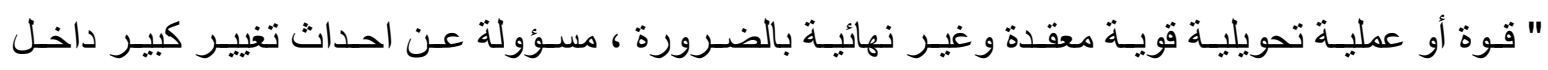

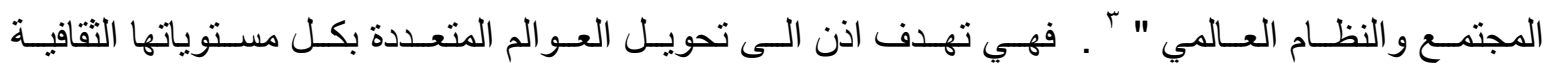

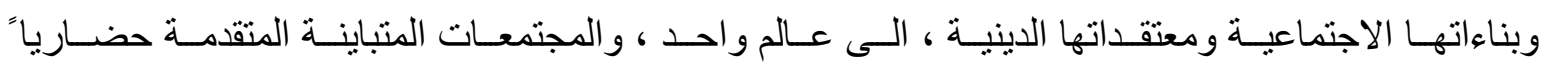

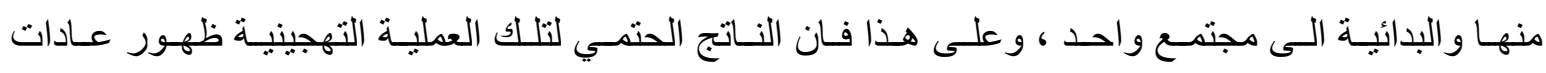

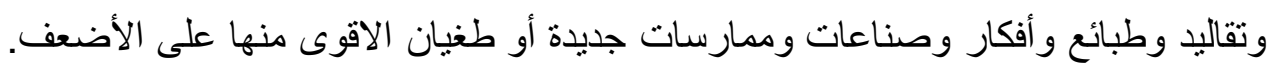

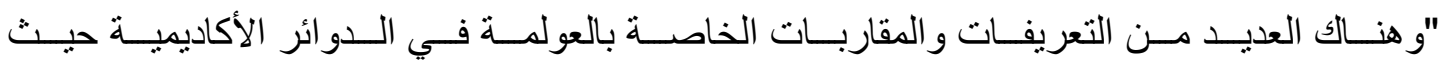

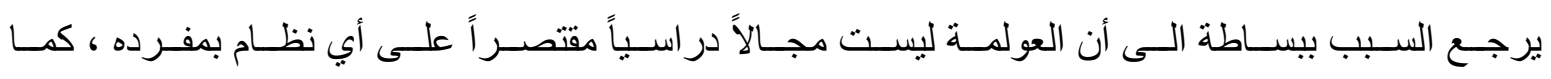

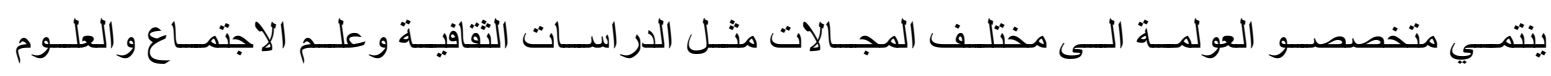

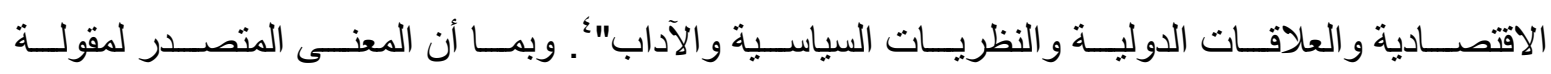

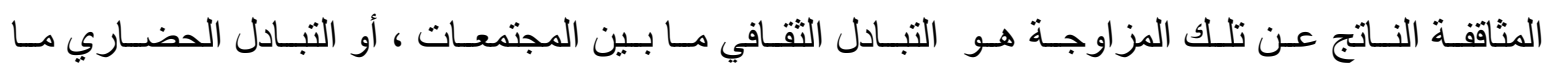

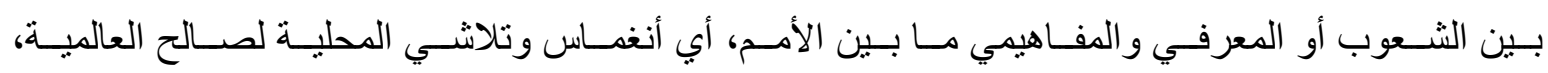

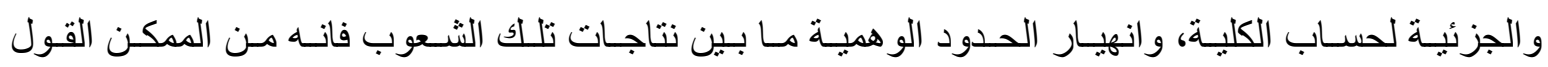
" تقع العولمة في القلب من الثقافة الحديثة، وتقع الممارسات الثقافية في القلب من العولمة".

ان "مــا نسـميه بالمسـرح العـالمي اليـوم لـيس في النهايـة ســوى محصــلة عمليـة التصـفية الثقافيـة

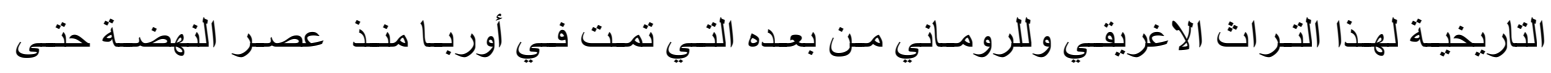

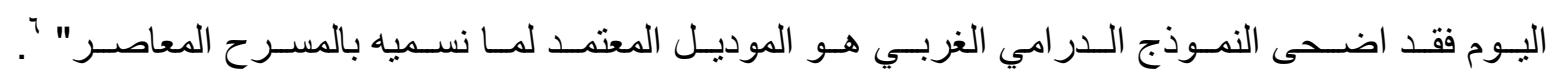

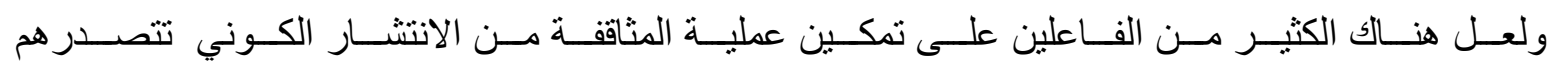

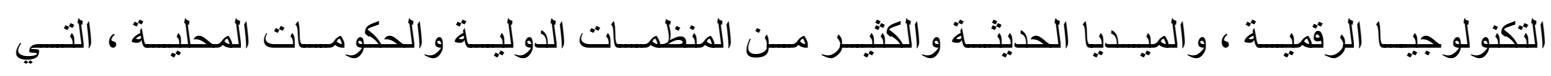

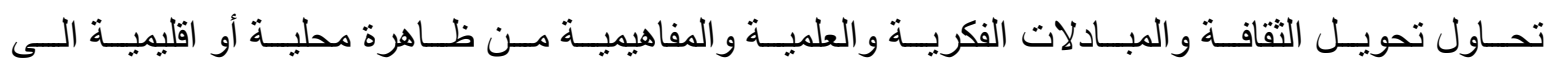

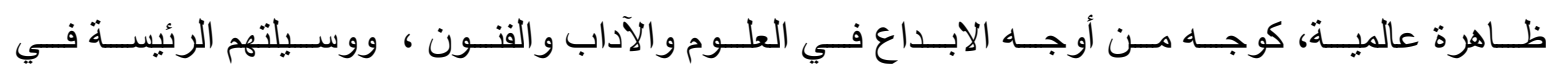

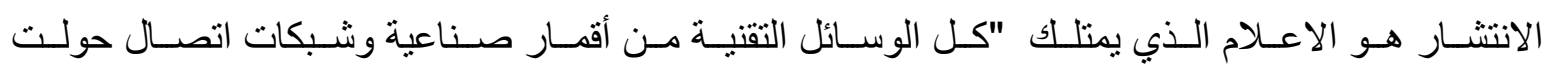
العـالم السى قريـة صـغيرة منو اصـلة وشـبكة الانترنـت وثـورة المعلومـات التـي احدثتها حولـت العـالم السى 


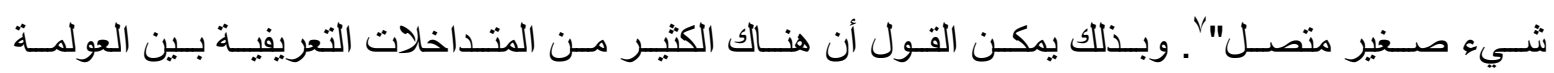

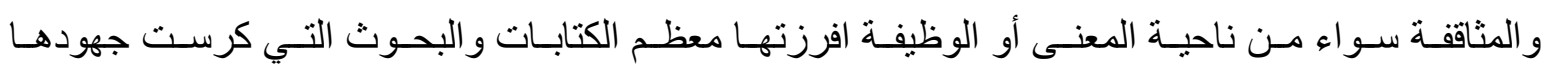

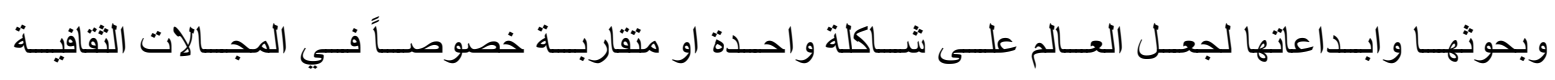
و الفنية.

\section{المبحث الثانيى : جدلية الناريخخ و عولمة الدراما :}

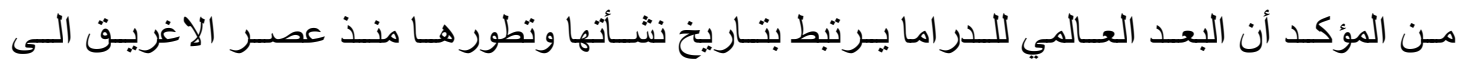

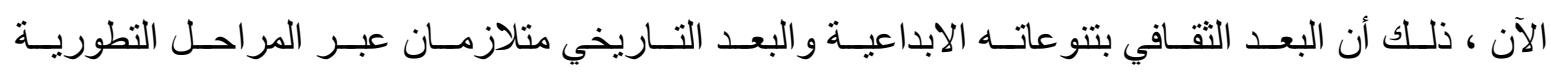

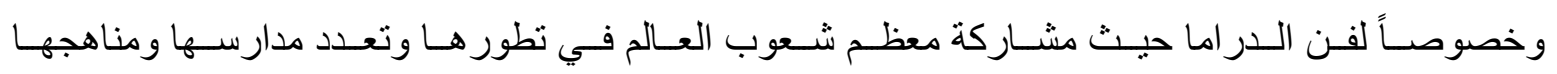

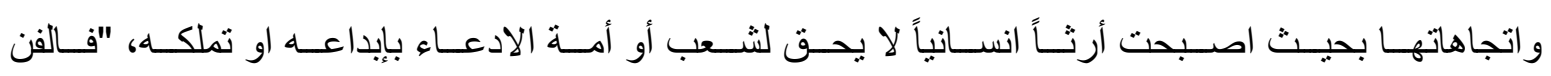

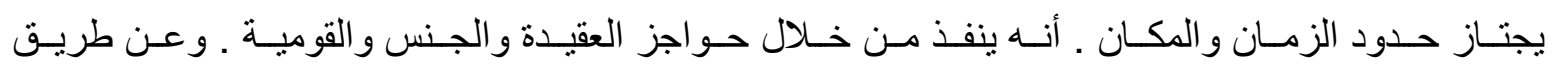
سحره نشاطر تجارب سوفوكلس وشكسبير وجوته وسترنبرج" . ل .

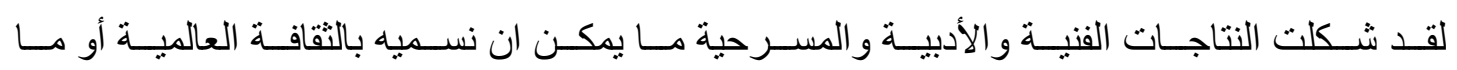

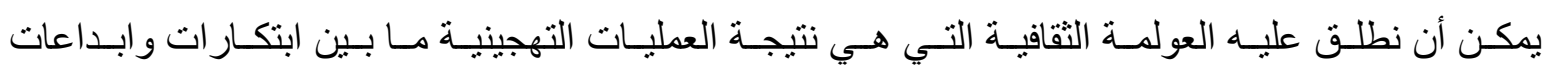

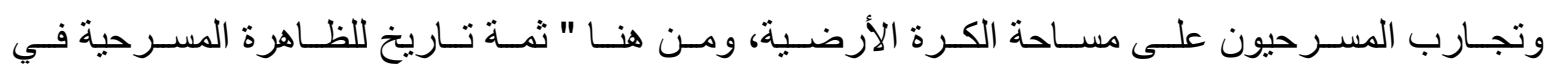

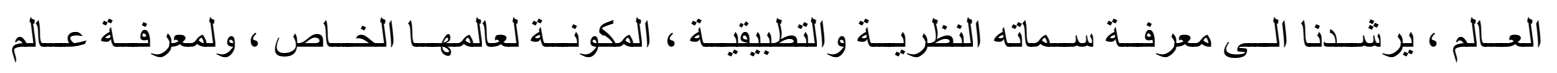

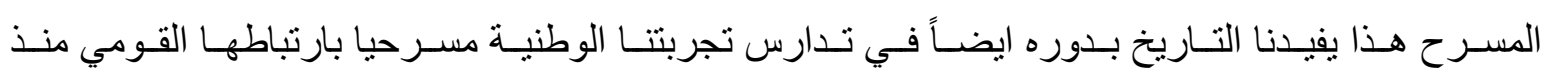

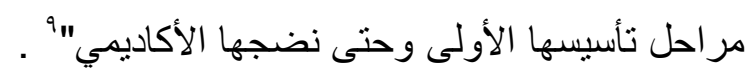

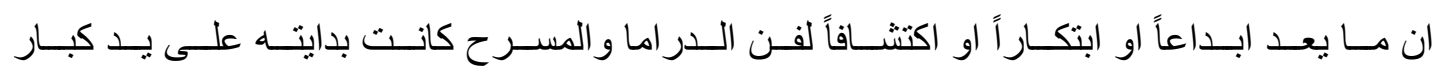
الكتــاب الاغريــق ( اســخلوس وســوفوكلس ويوربيــس ) و التــي كانــت مسـرحياتهم مصــدر التنظيـر

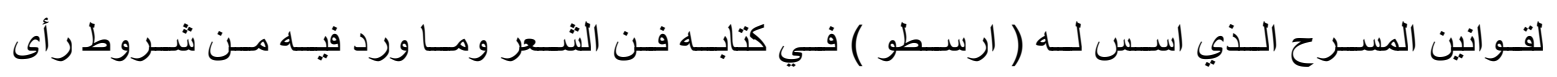

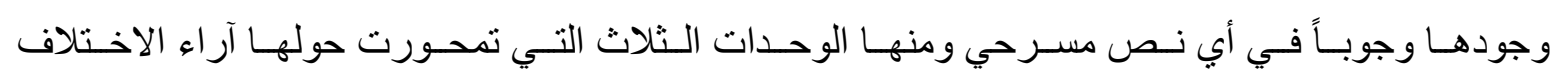

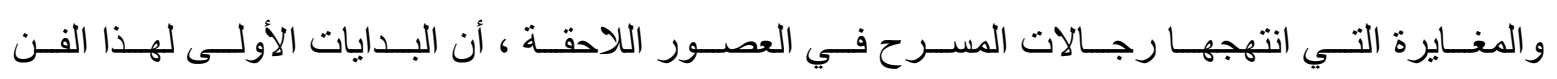

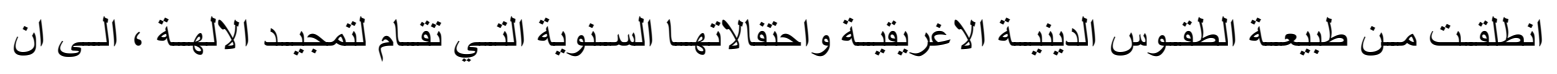

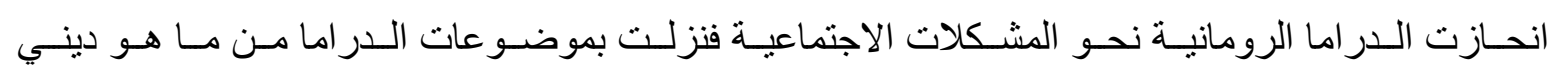
الى ما هو دنيوي.

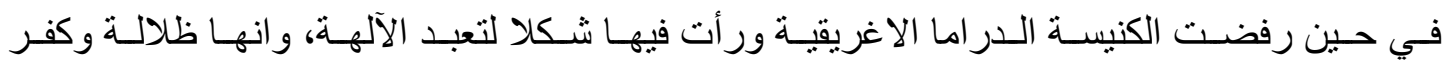

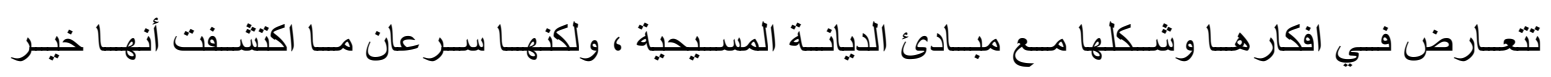

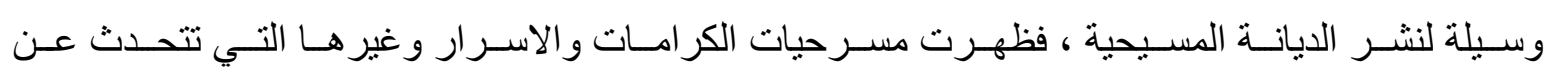

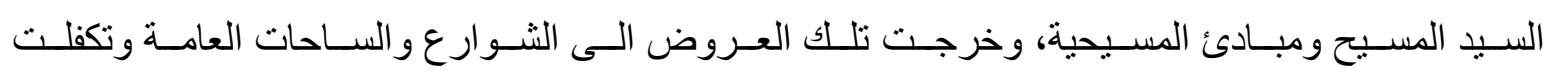

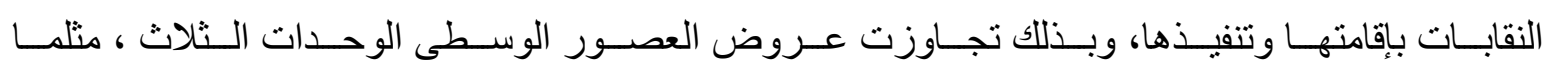

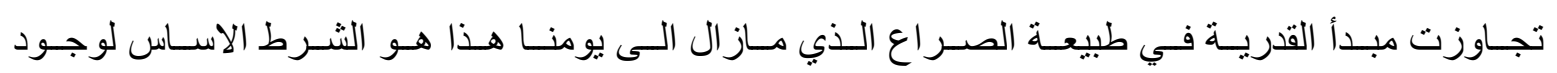




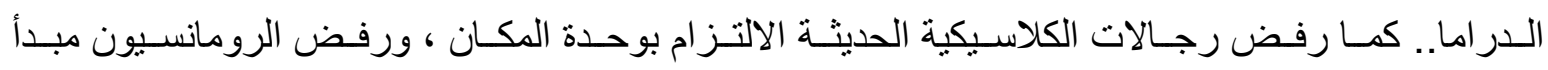

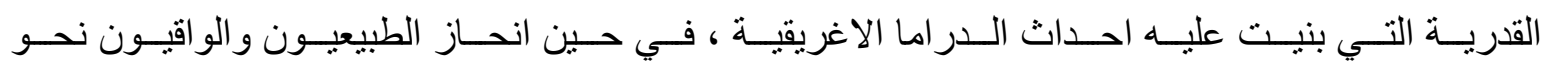

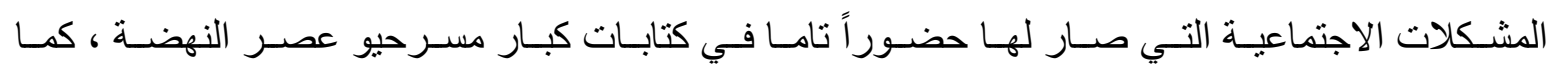

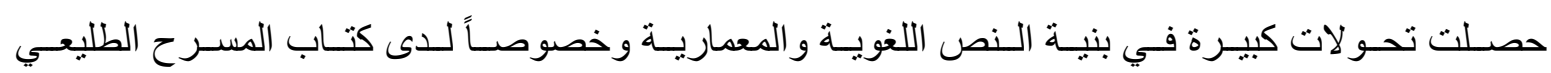

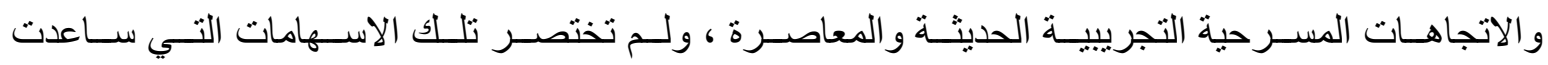

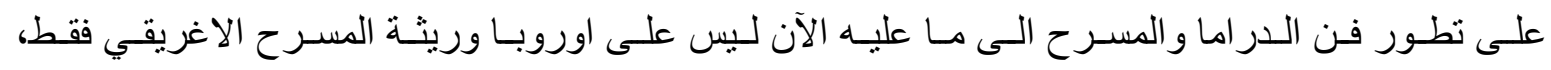

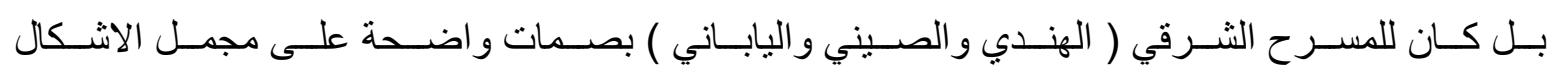

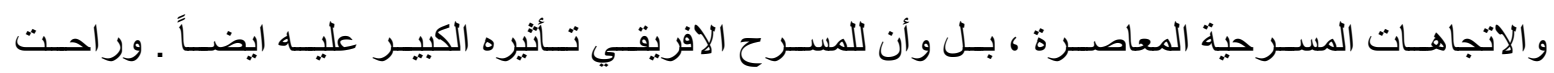

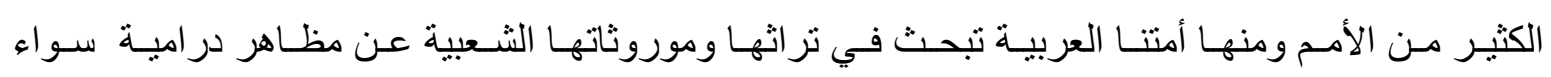

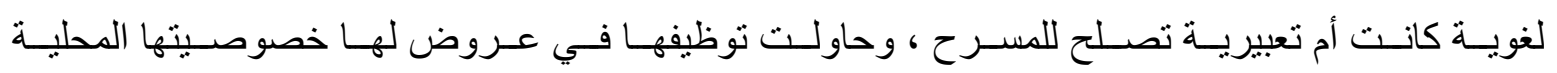

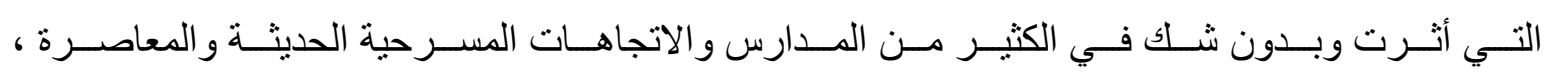

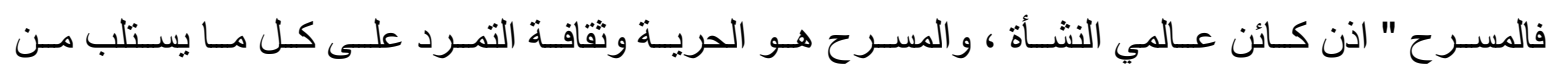

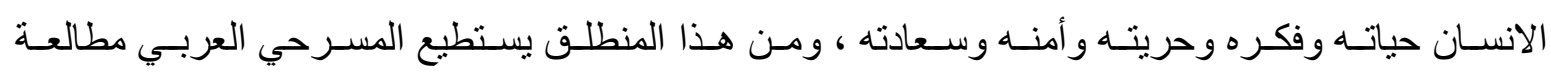

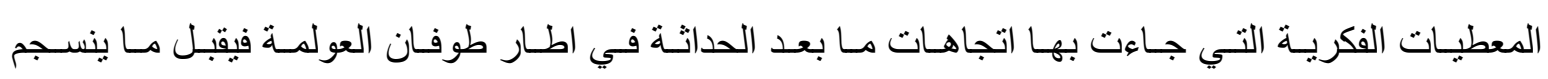
مع ذاته ويغني منظومته الفكرية وو عيه الجمالي ويرفض مالا ينسجم"'. و علـى هــا يمكـن القـول أن النتـاجين الــر امي و المسـرحي تجـاوز ا مفهـومي الزمــان و المكـان فـي

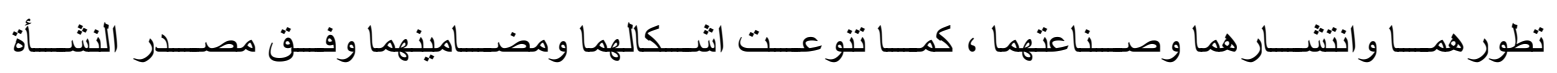

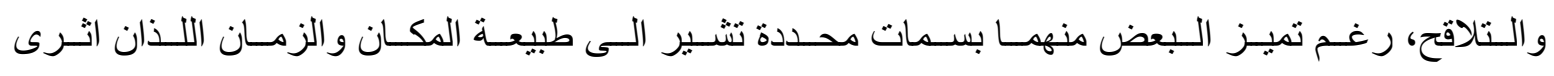

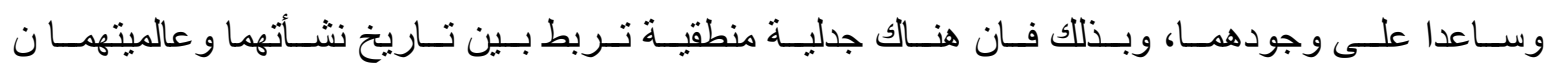
بحيث لا يمكن وضع حدود فاصلة بينهما .

\section{ما اسفر عنه الاطار النظري من مؤشرات}

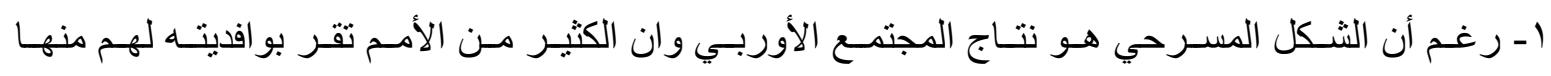
إلا أن معظم المضامين التي يطرحها هي محلية، رغم نزو عها نحو ابعاد انسانية .

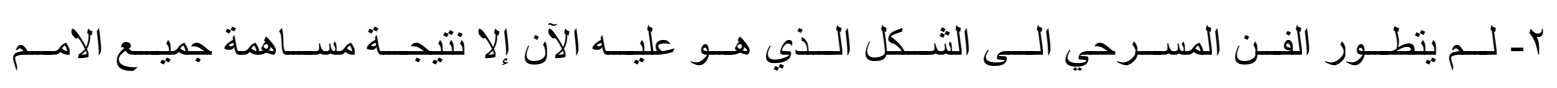
والقوميات في ذلك ومن خلال تجاربهم القومية المحلية التي بنيت على نتاجات عالمية.

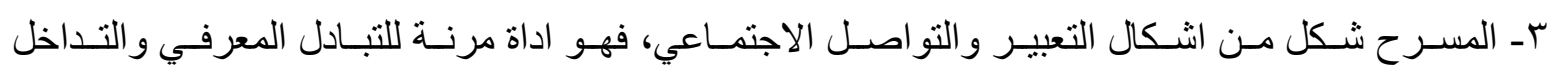
الثقافي بين الامم.

\section{اجزاءات البمث} أولاً : مجتمع و عينة البهث : - مسروية ( الاسكافي ) وقد افتنارها الباحث أنموذجاً لأنها : أ - ت تنفق وهدف البحث. 
ب - تطرح مشكلات آنية يمر بها العراق نتيجة تدخلات اقليمية وعالمية . .

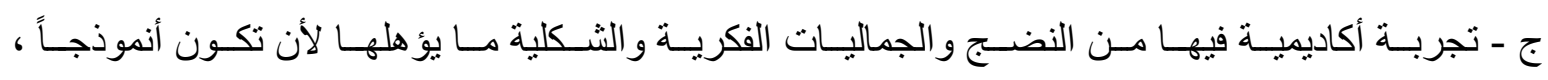

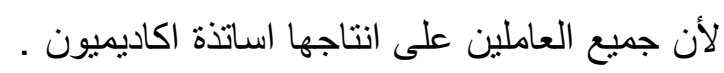
د. - مشاهدة الباحث للعرض المسرحي مع وجود تسجيل له على قرص مدمج .. .

ثانياً : منهمج البحث: المنهمج الوصفي التهليلي . ثالناً : طرائق جمع المعلومات :- نتمثنل في : ما اسفر عنه الاطار النظري من مؤشرات

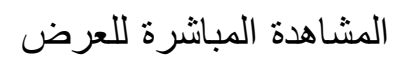
تسجيل العرض على قرص ليزري .

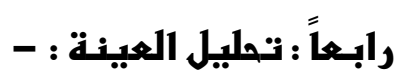
مسرحية الاسكافي، تأليف واخر اج د. عقيل مهدي، تمثيل : د ـ خالد أحمد مصطفى، د. ـ حسين على

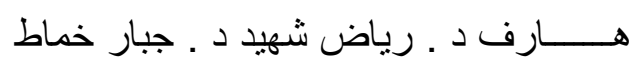

\section{مكاية المسبرصية : - مائ}

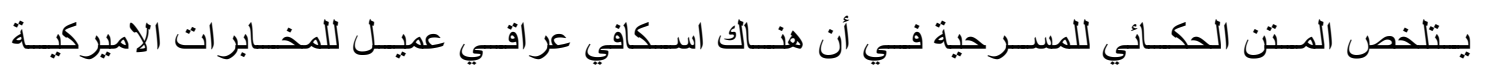

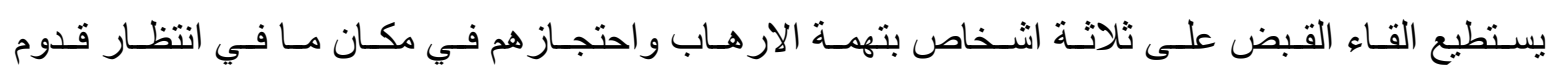

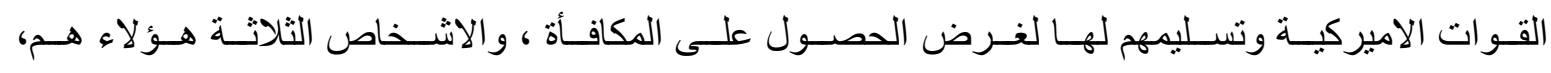

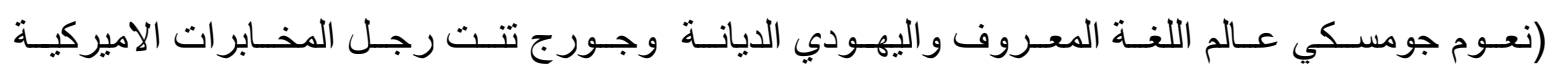

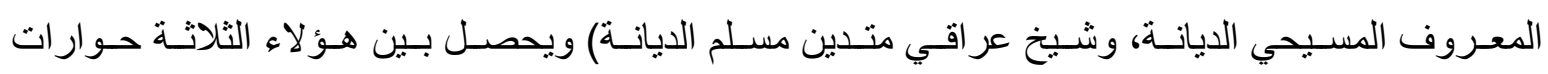

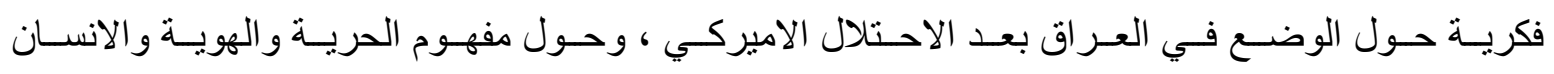

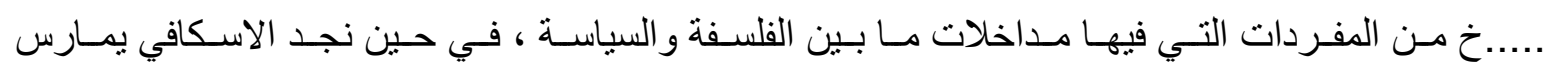

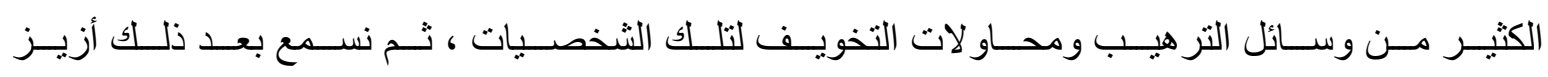

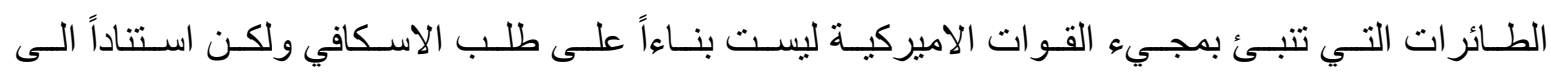

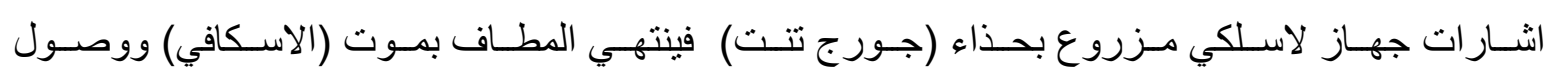

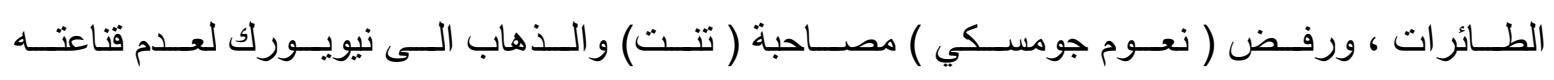
بأفكاره وأهدافه، وفضل البقاء في العراق مع الثيخ ليكون اكثر قرباً من الثعب المظلوم....

توليل المستروصية :

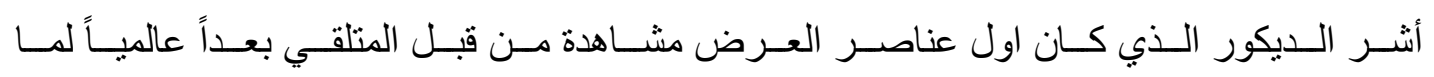

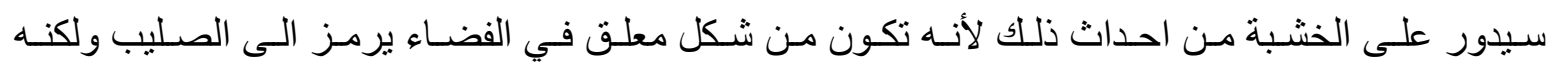

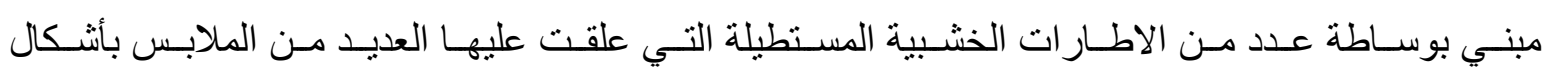

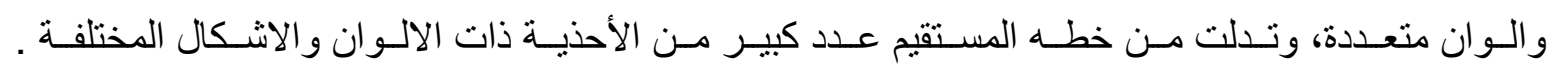

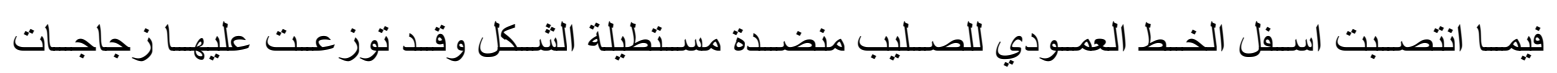




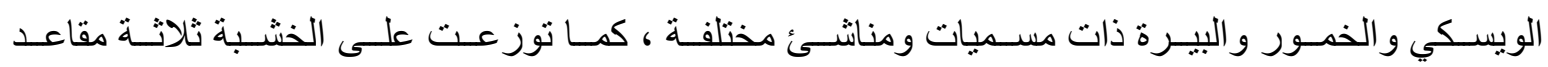

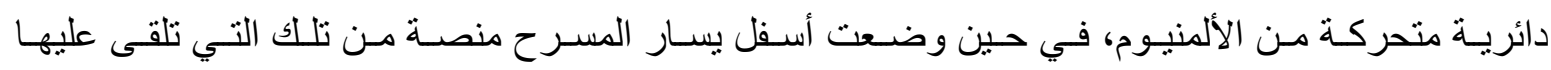
الخطب الرسمية، وفي جوارها على الارض نشاهد سجادة الصلاة الاسلامية .

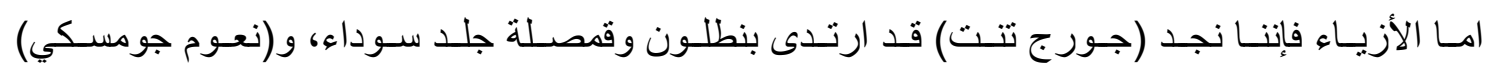

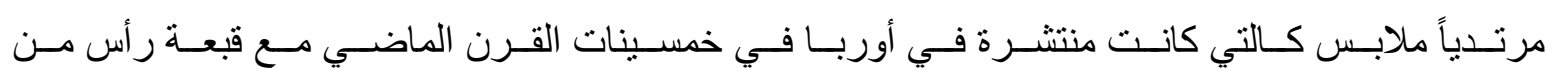

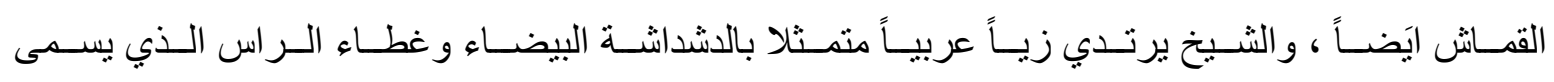

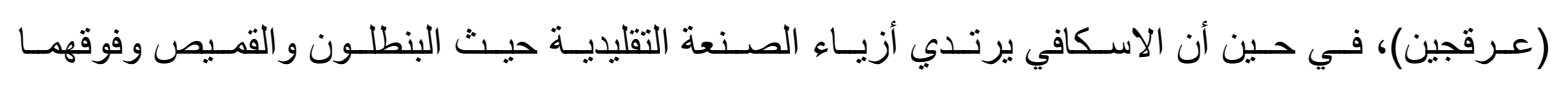
( صدرية ) من الجلد كالتي يستخدمها مصلحو الأحذية في بلادنا أو في الغرب.

ومنــ بدايـة العـرض حيـث الخطبـة المقدمـة التـي يلقيهـا الاسـكافي يـدرك المشــاهدون ومـنهم الباحـث

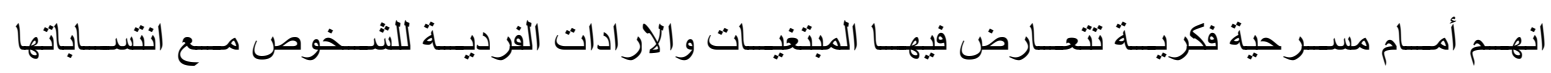

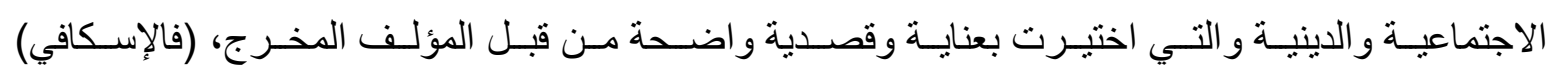

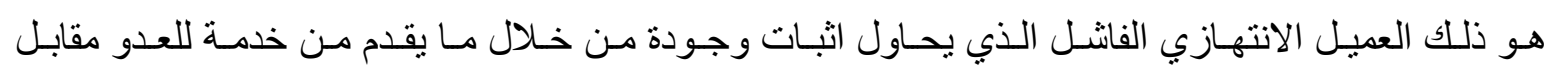

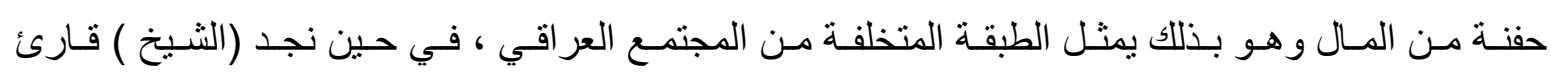

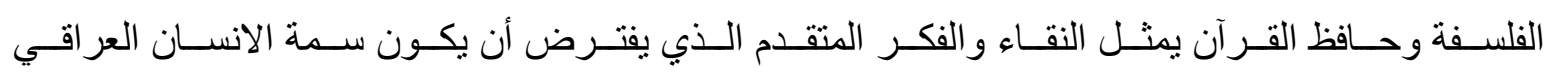

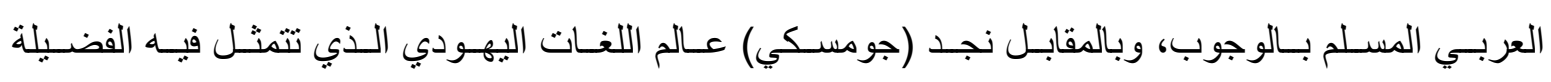

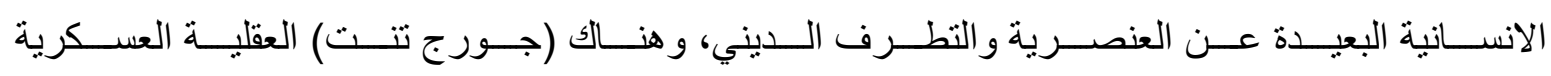

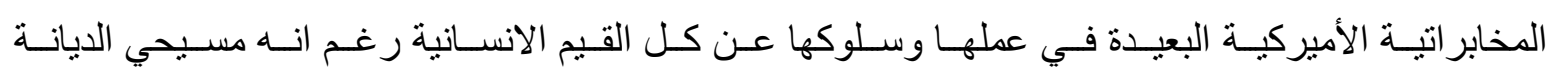

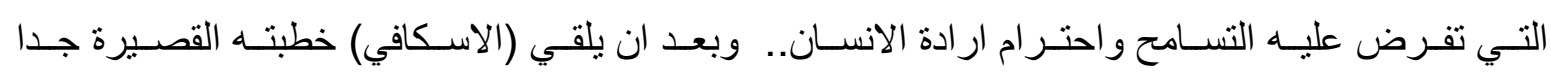

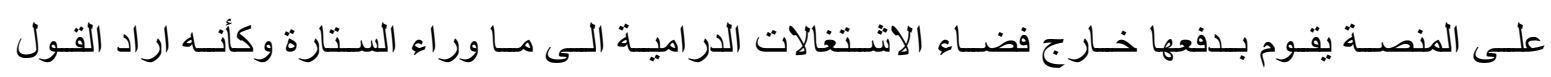
أن الخطابات ما عادت ذا جدوى في هذا الزمن ، بل الافعال هي سيدة المواقف.

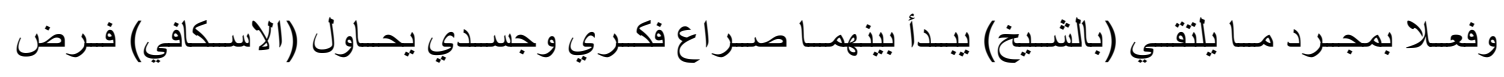

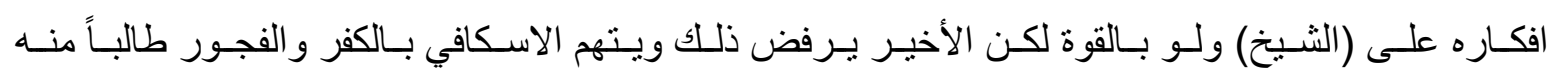

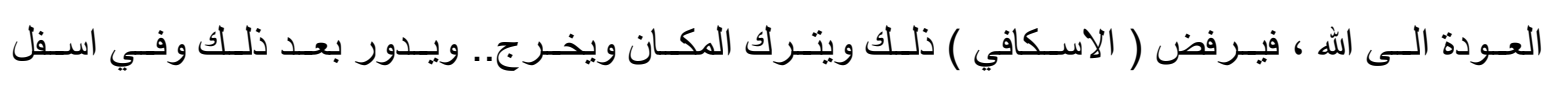

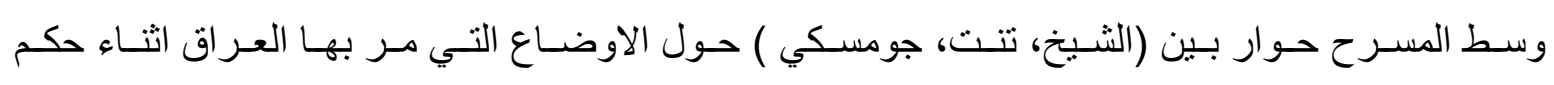

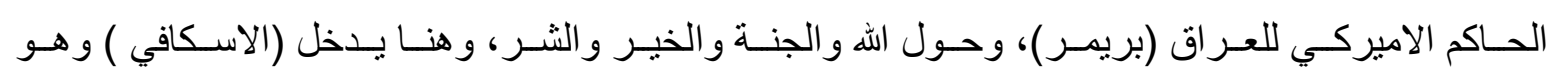

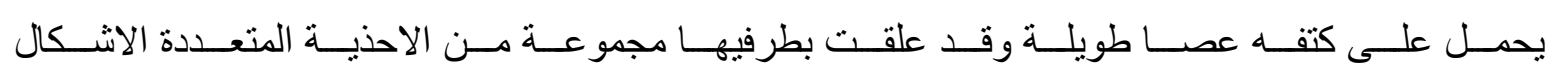

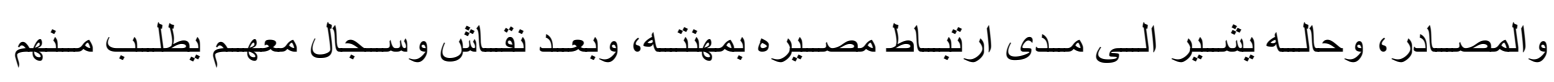

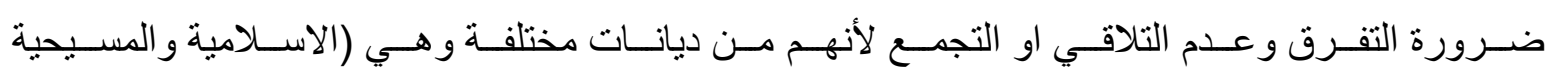

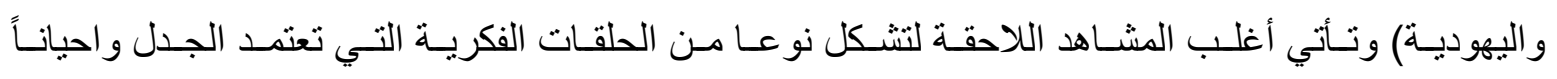

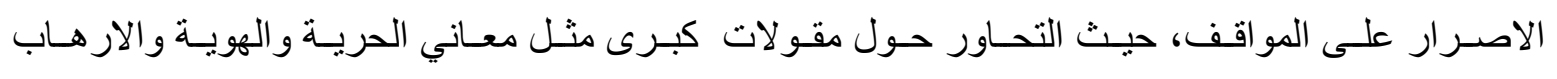

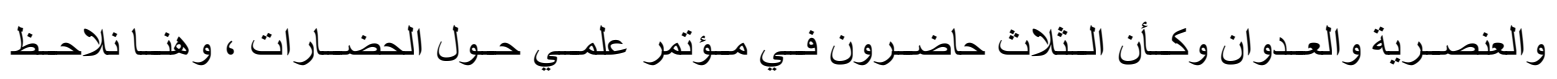




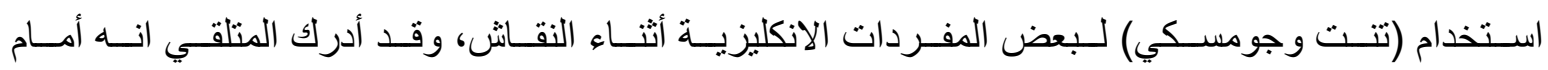

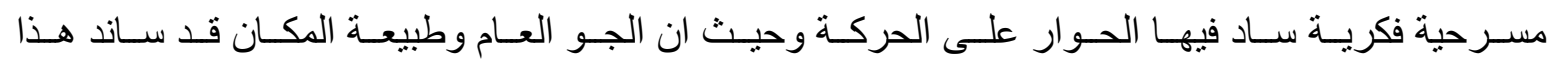

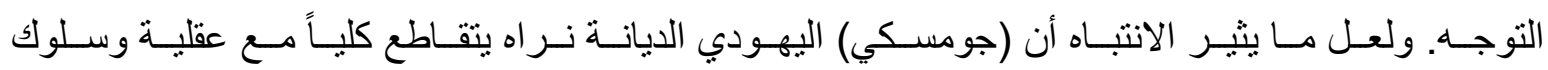

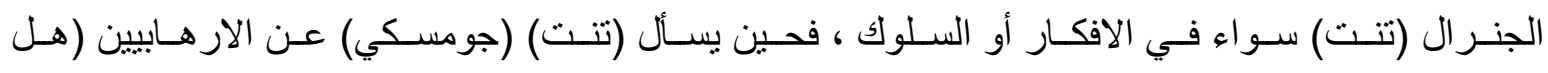

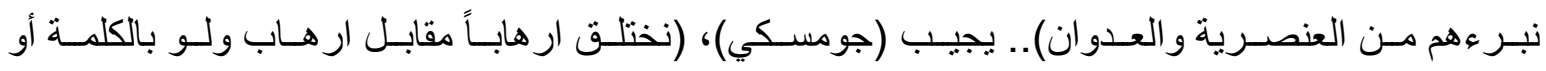

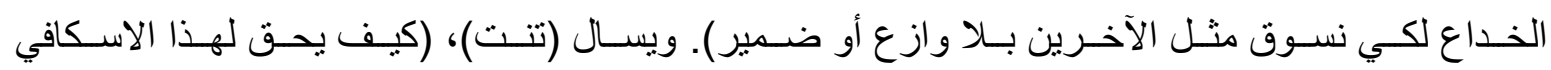
العر اقي أن يحتجزنا هنا؟) فيجيبه (الثيخ) ، (انها واحدة من الاعيبكم).

ويـــلـ الاسـكافي مـرة أخـرى ويقـوم باللعـب بالأحذيـة المعلقـة بالصـليب وكأنـهـ يتلاعـب بمصـيره

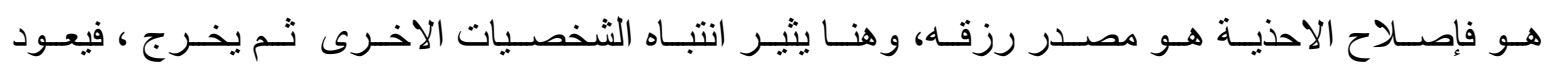

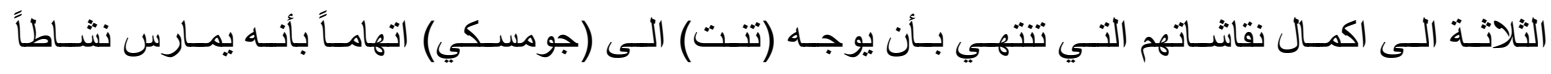

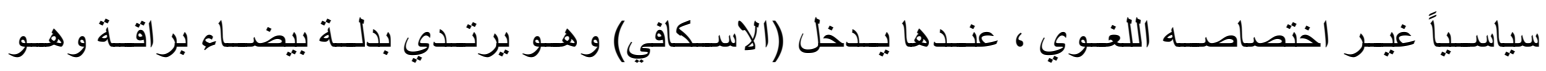

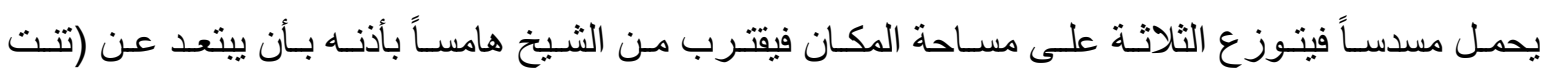

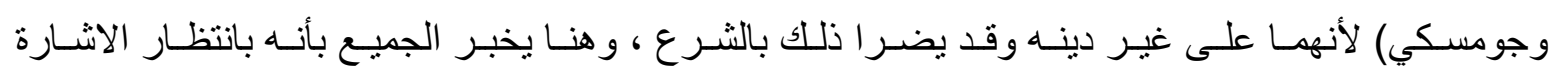

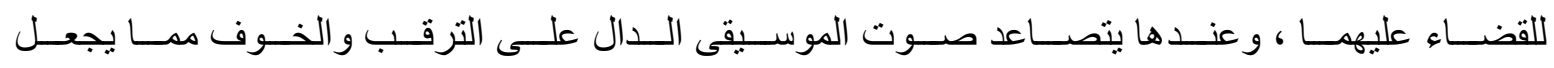
الثخصـيات الـثلاث ينتابهـا الثــور بـالقلق، ويعـود الثلاثـة للتحــاور حـول الاصــلاح و المناقثـة الجـادة

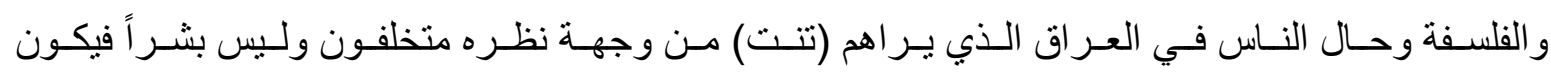

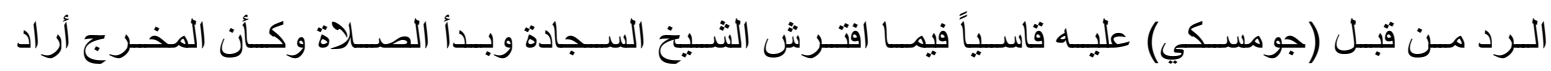

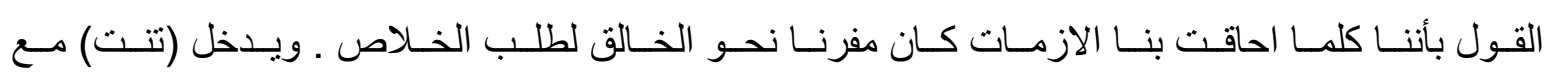
(الثـيخ) بحـوار عـن العـرب وكيـف يفكرون ـ و عندها يـدخل (الاسـكافي) مـرة اخـرى وهـو يحمـل عـداً

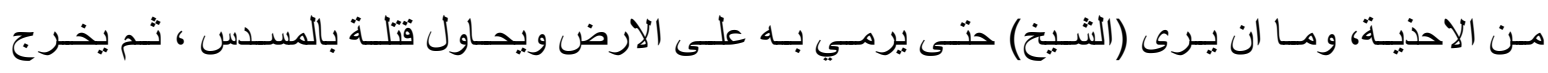
مـن جيــه هـاتف نقـال يحـاول بواســته الاتصــال بـالرئيس الاميركي (بـوش) دون جـدوى ثـم يحساول

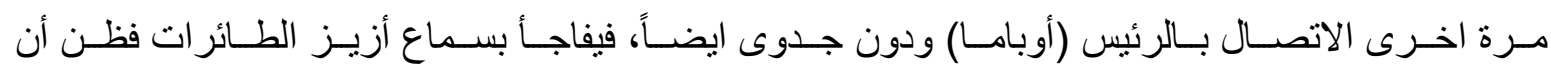

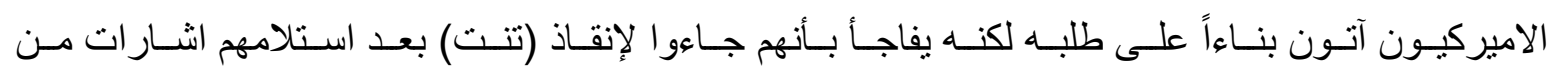

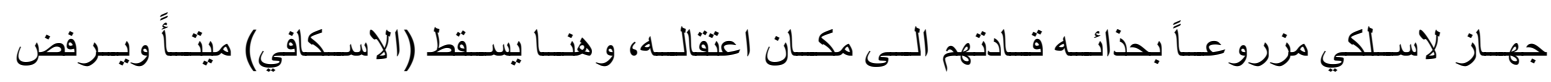
(جومسـكي) مصساحبة ( تنـت ) و الصـعود الـى الطـائرة والـذهاب الـى نيويـورك مفضـلاً البقـاء مــع الثـيخ وتحت حمايته ....

\section{|لنتائج ومناقشتما}

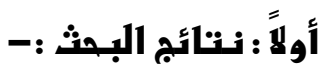

من خلال ما ورد في الاطار النظري من مؤشرات وما استخلصه الباحث عند تحليل العينة يمكن تنبيت النتائج الآتية: 


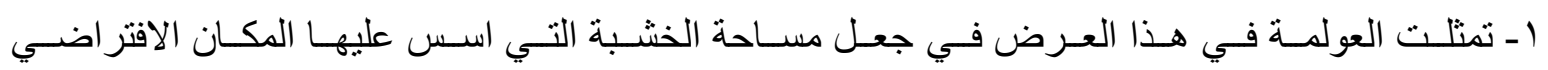

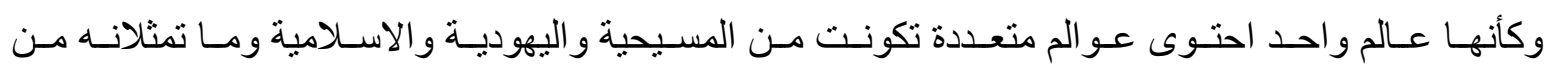
عادات وتقاليد وثقافات و اعر اف. و واه

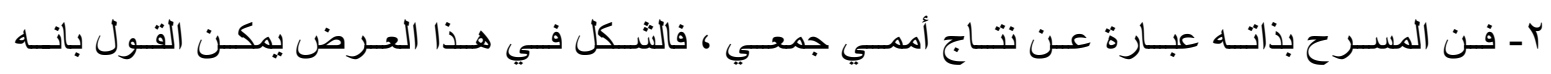

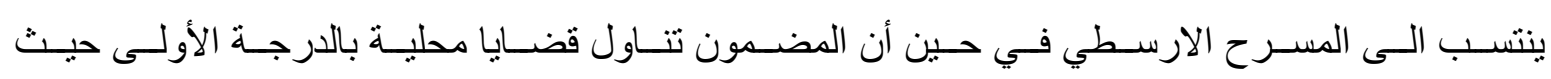

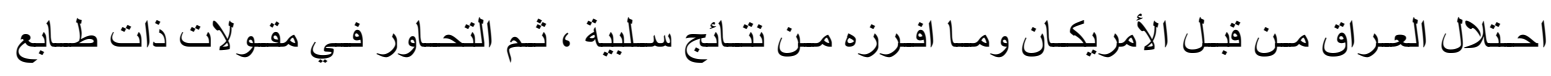
انساني عالمي .

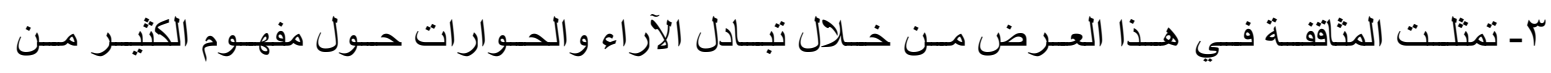
المقو لات كالحرية و الايمان و الكفر والانسان والارهاب ...... . . ل

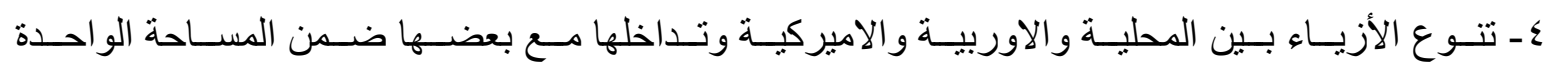

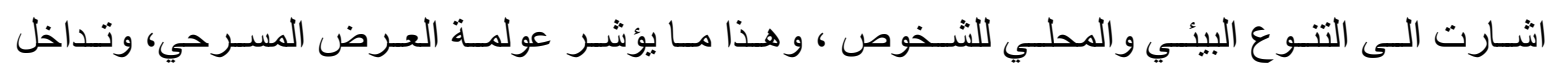
الثقافات فيما بينها .

هـ ان اســتخدام بعـض المفـردات الاجنبيـة اثتــاء الحــوارات ســواء مــن قبـل ( جومسـكي) أو ( تتــت )

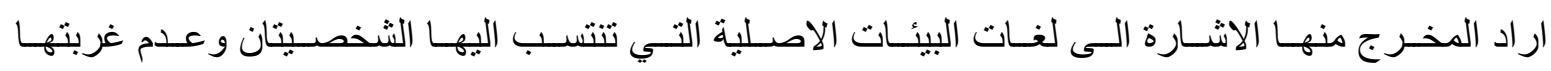
عن لغة العرض الاساسية التي هي العربية .

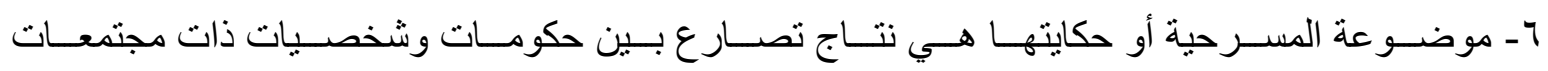

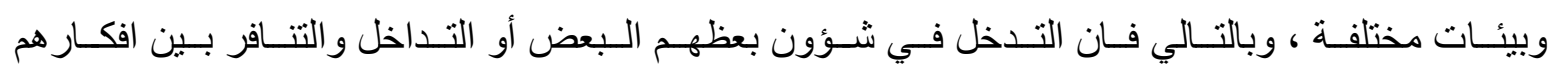

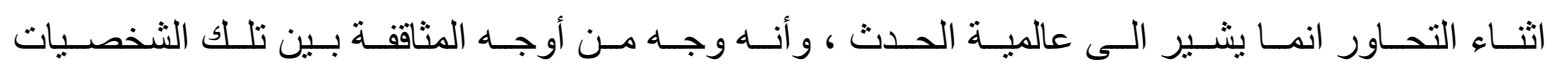
وبناءاتها الفكرية والمفاهيمية .

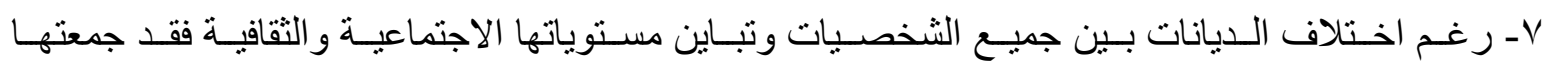

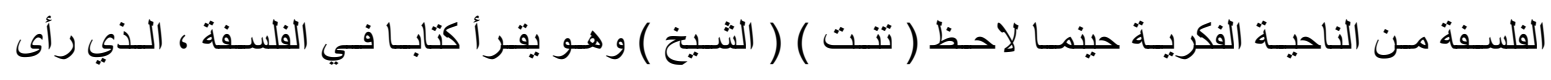
فيها الأخير أنها لا تتعارض مع الثرع بل بالعكس من ذلك فقد اثار استغراب ( تنت ) ) .

\section{ثانباً : الاسنتنـناجات :}

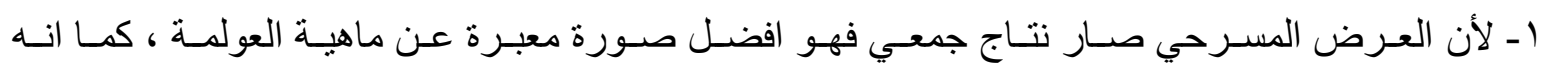
من الممكن ان يكون أداة صالحة للمثاقفة بين الامم و الثعوب .

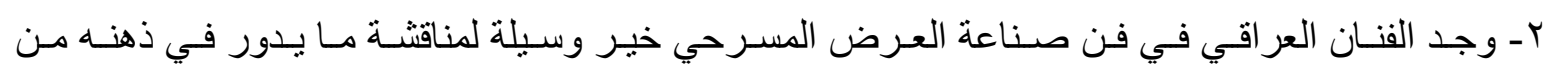
مفاهيم حول الكثير من المقو لات التي ذكرناها ، كما أنه أداة مهمة لطرح معاناته ومعاناة شعبه

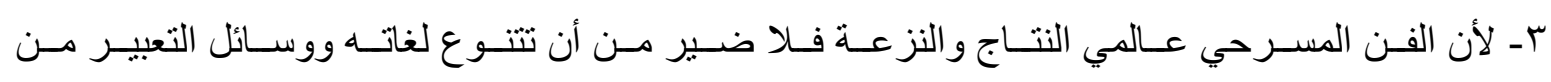

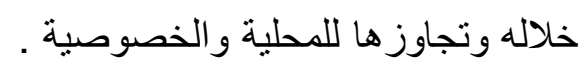




\section{ثنالنًاً : التنوصيات :-}

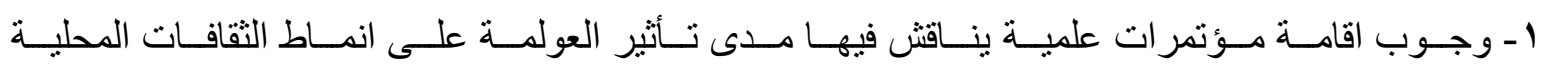

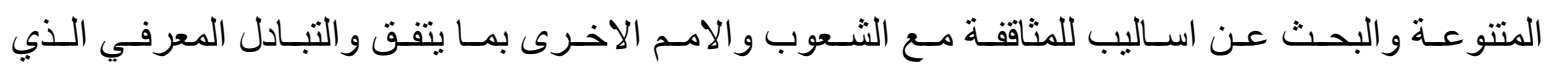
يثري جميع الاطر اف . م.

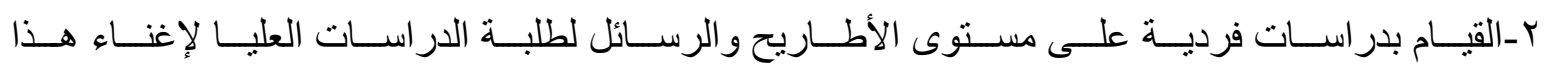
الموضوع واثر اءه علمياً.

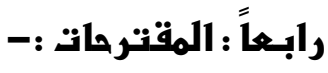

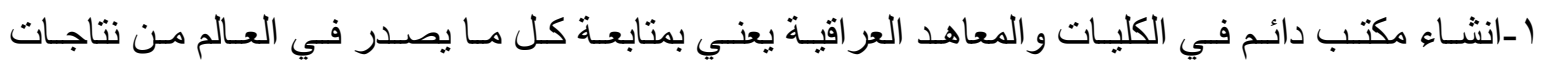
فكرية تتناول بالدر اسة والتحليل مفهومي العولمة و المثاقفة .

\section{الهوامش}

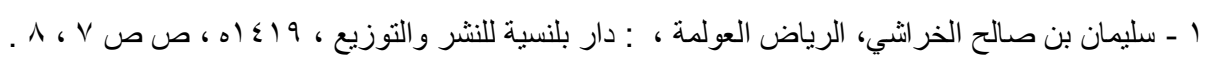

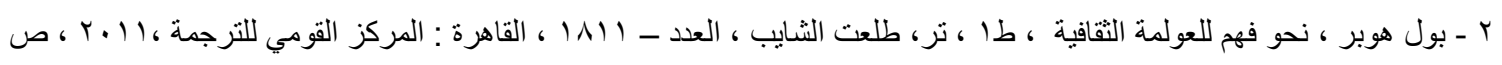
rT-.

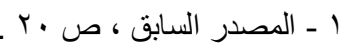

ץ - أنابيل موني وبيتسي ايفانز ، العولمة المفاهيم الأساسية ، طا ، تر ، آسيا دسوقي ، بيروت : الثبكة العربية للأبحاث و النشر ، 9 ، . ب ،

ص ص 11

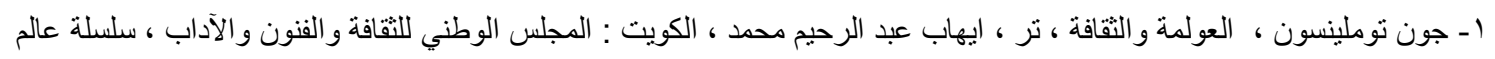

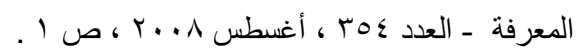

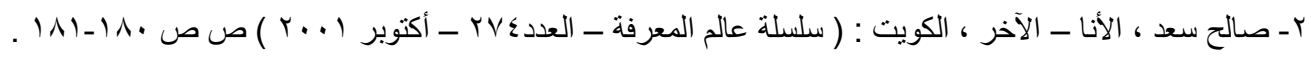

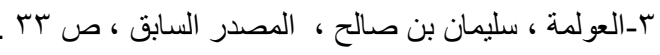

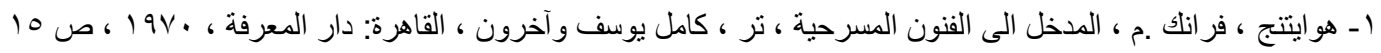

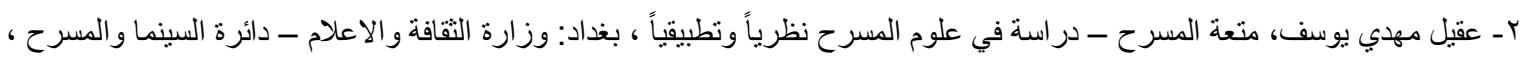
. $\leqslant$. ـ ـ عبد الفتاح قلعه جي ، المسرح الحديث ـ ـ الخطاب المعرفي وجماليات النتكيل، دمشق: اتحاد الكتاب العرب (سلسلة الدراسات ـ (1 ) . r ا

قاتمبمة الإمادر

أنابيل موني وبيتسي ايفانز، العولمة المفاهيم الأساسية ، طا، تر ، آسيا دسوقي ، بيروت : الثبكة العربية للأبحاث و النشر ، 9 . . ب .

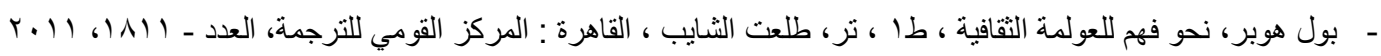

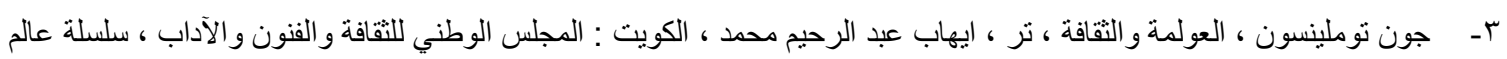

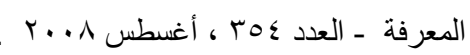

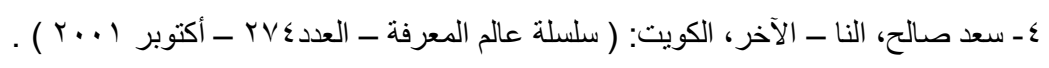

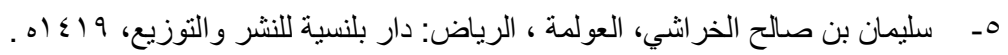

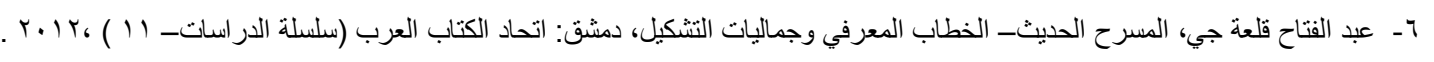

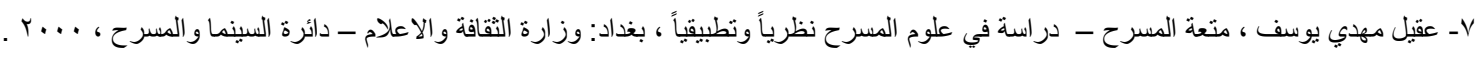

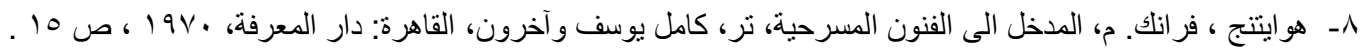

